\title{
A Wild Flax of the Dry Prairies
}

by Keith Best, Swift Current

Linum, a genus of annual or perennial herbs of the relatively small flax family (Linaceae), consists of between 90 and 100 species. Linen thread, manufactured from the cultivated flax ( $L$. usitatissimum) is the most important vegetable fiber from the standpoint of long-continued and widespread usage. Its use dates back to the dawn of history, which is indicated by its similarity in European languages. Thus, Greek linon, Latin linum, Anglo-Saxon linen, German leinen and Swedish linne all refer to flax. Our English words "line" (literally, linen thread), "linen", and "linseed" are all from the same source.

Lewis' Wild Flax or Prairie Flax (Linum lewisii) was named by the botanist Pursh in honor of Capt. Meriweather Lewis of the famous Lewis and Clark expedition, who first collected the plant. Lewis found fields of the wild blue flax in Montana and was keenly interested in this perennial-rcoted species.

Growing from a woody, perennial taproot, the densely tufted stems are erect, often branched above and up to $2 \frac{1}{2}$ feet in height. The narrow linear leaves are erect and borne alternately on the stem. They are from $1 / 2$ to 1 inch long, sharp-pointed, hairless and without stalks. The flowers are blue (rarely white), stalked and usually occur in several flat-topped clusters. The 5 blue petals are about $3 / 4$ inch long, but soon fall off. The sepals are 5 in number, and up to $1 / 4$ inch long. They have 3 to 5 nerves, are sharp-pointed, and remain attached to the seed pod. The seed pod or capsule consists of 5 chambers, each containing two elongated, lensshaped seeds.

Although common over the prairies and foothills where it often forms dense stands, it is also found as high as 10,000 feet in the coniferous timber lands of Colorado. It is rated as worthless, poor, or when young and tender in the spring, occasionally fair forage. The Klamath Indians produced a remarkably strong, fine fiber from the stems which they made into strings and cords. Today it merits cultivation as an ornamental. 


\section{Habenaria obtusata and H. bracteata}

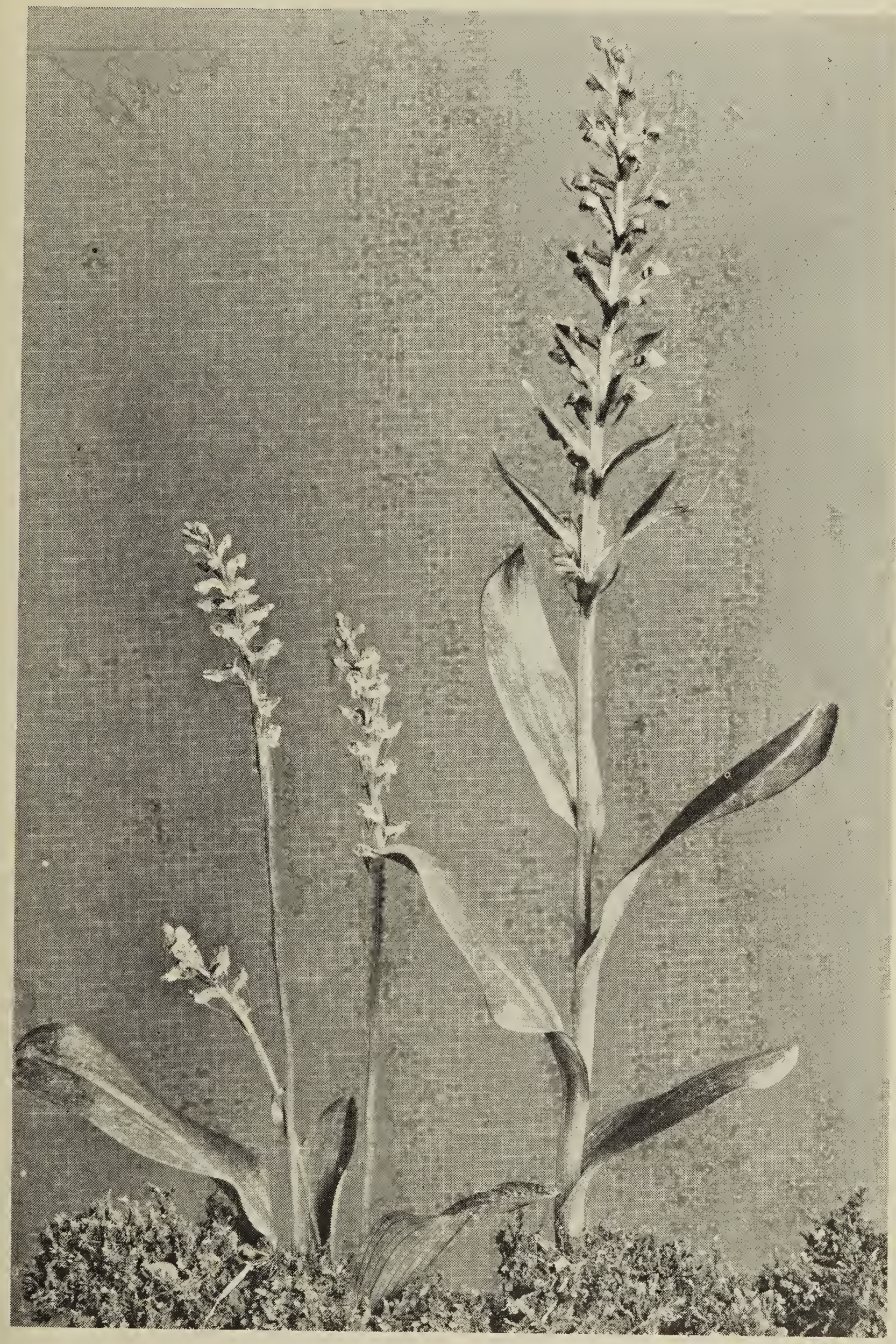

Photo by the late W. C. McCalla.

NATIVE ORCHIDS OF NORTH AMERICA

The two orchids shown here are both widespread across the northern parts of North America. The smaller Blunt-leaf Orchid, Habenaria obtusata (Pursh) Richards., which has a single leaf, is frequent in wet spruce woods. The larger Long-bracted Green Orchid, Habenaria viridis var. bracteata (Muhl.) Gray is fairly common in meadows and the borders of sandy woods even south of the coniferous forest. Because of their greenish color these orchids are not conspicuous but it is always thrilling to see them in their native habitats. 